FACTA UNIVERSITATIS

Series: Physical Education and Sport, Vol. 18, No 3, 2020, pp. 649 - 665

https://doi.org/10.22190/FUPES200729062O

Research article

\title{
PEDAGOGICAL, COGNITIVE AND METHODOLOGICAL ASPECTS OF DIGITALISATION IN PHYSICAL EDUCATION
}

\author{
UDC 796:371.3
}

\section{Jelena Osmanović, Jelena Maksimović, Milica Dimitrijević}

Faculty of Philosophy, University of Niš, Niš, Serbia

\begin{abstract}
The implementation of digital education technology into the school subject of physical education (PE) has become a challenging trend of contemporary pedagogy. This paper emphasises the importance of the pedagogical, cognitive and methodological aspects of digitalisation in PE. The research presented examined the attitudes of $P E$ teachers in primary and secondary schools towards digitalisation in PE. The research has three goals: 1. Theoretical-the review of all the international and national sources relevant for the perception of the theoretical aspects of introducing digitalisation into physical education teaching; 2. Cognitive-the study of PE teachers' attitudes towards digitalisation in $P E$ as a school subject; 3. Applicable-a contribution to raising awareness about the importance of PE improvement. The methods used in the empirical research were the descriptive method, the survey and scaling technique with a questionnaire as the instrument and the assessment Likert-type scale (DOUF/DEIP). The questionnaire comprised of four closed-ended questions and the scale containing 40 items. The sample included 126 PE teachers from Serbia. The obtained results were calculated by the SPSS software version 24, used for the statistical data processing. The following statistical parameters for displaying results were used: frequency $(f)$, percentage $(\%)$, arithmetic mean $(M)$, standard deviation $(S D)$, Pearson's chi-squared test ( $\chi 2)$, the t-test and ANOVA F-test. The research results show that PE teaching is undergoing digitalisation and that teachers have positive attitudes towards digital competences, technologies and the connection between digital education and quality of teaching, schoolchildren's academic achievements and the teacher's role.
\end{abstract}

Key words: Physical Education, Digitalisation, Technology, Primary and Secondary School Teachers, Empirical Research

Received July 29, 2020 / Accepted December 01, 2020

Corresponding author: Jelena Osmanović

Faculty of Philosophy, University of Niš, Ćirila \& Metodija 2, 18105 Niš, Serbia

Phone: + 38118514312 •E-mail: jelena.osmanovic@ filfak.ni.ac.rs

두 2020 by University of Niš, Serbia | Creative Commons License: CC BY-NC-ND 


\section{INTRODUCTION}

Physical education (PE) is a school subject taught in the majority of primary and secondary schools all over the world. Its primary goals are the stimulation of children's growth, integral personality development, posture, motor skills, habits of regular physical exercise and playing various sports, as well as schoolchildren's positive attitudes towards PE, exercise, sports and healthy lifestyles (Kretschmann, 2010; Džinović \& Martinović, 2018; Ristić, 2018a; Višnjić \& Marković, 2018). PE used to be one of the most favourite school subjects, yet nowadays, it is rarely the case. Namely, schoolchildren have developed the habit of skipping PE classes recently, which is reflected in a new sedentary lifestyle (Dobraš, Dragosavljević, Vučković, Gadžić, \& Lepir, 2013). Children and adolescents frequently suffer from various health issues, such as obesity, physical inactivity and cardiovascular diseases (Gordon-Larsen, McMurray, \& Popkin, 2000; Goran \& Reynolds, 2005; Lin, Mamykina, Lindtner, Delajoux, \& Strub, 2006; Džinović \& Martinović, 2018). Also, a growing number of adolescents with foot disorders (Mihajlović, Smajić, \& Sente, 2010) and posture problems have been reported, which consequently results in serious spine conditions. Therefore, insufficient motor and physical activity affects the quality of PE classes.

The children and adolescents of today belong to a digital generation. Their growth and upbringing are unavoidably influenced by the omnipresent technology of the contemporary world. Modern technologies have an impact on children's cognitive, perceptive and sensorimotor abilities (Mangen, 2010), whose interaction yields experiences significant for creating their own view of the world and their further personality development, skill building for problem solving, creative thinking and emotional well-being (Baltazarević \& Baltazarević, 2019). The introduction of innovations and technologies into the education system has thus become a necessity and challenge for contemporary pedagogical science. The possibilities for introducing information technologies into school subjects are enormous since they permeate every segment of the education system and facilitate cooperation with the agents outside of it (Sandeep, 2011). As regards PE, Dobraš et al. (2013: 24) state that teaching materials are mainly incompatible with students' needs, which affects their motivation for PE classes. The task of pedagogy is to contribute to the enhancement of PE teaching and of schoolchildren's physical activity and general health. Digital education in PE appears to be an appropriate solution accorded with the trends of contemporary pedagogy.

This research aimed at examining PE teachers' attitudes towards digital education in PE classes concerning the following research tasks: digital competences and digital education in PE teaching, technologies used in PE classes, the connection between digital education and the quality of teaching, students' achievements and the teacher's role in PE teaching.

\section{METHODS}

Technological advancements have permeated every sphere of contemporary life. Belonging to social sciences, pedagogy has readily accepted the challenging task of introducing technologies into education and teaching. Teaching has evidently altered its framework owing to technologies applied in planning, realisation and evaluation of teaching-learning practices. Technology and digital devices have become an integral part of contemporary education, besides teachers and students. The aspect of digitalisation is 
particularly evident in teaching the school subject of PE since it differs from other school subjects in many ways. PE classes are characterised by teachers and students being very active, involved in creating and maintaining healthy habits, positive attitudes towards sport, working-out, exercise and lifestyle in general. Their flexibility, dynamics and uniqueness make them suitable for the application of technologies with the purpose of the further advancement of teachers' competences, students' fitness and physical activity, as well as the improvement of teaching itself.

Therefore, the question is: Is the school subject physical education undergoing digitalistaion? The objective of this research was to examine primary and secondary school PE teachers' attitudes towards digital education of this school subject. The research goal and tasks were based on the study of teachers' attitudes towards digital competences, digital education and technologies that could be used in PE classes, as well as on determining the link between digital education and the quality of teaching, students' achievements and the teacher's role in PE teaching.

The research largely contributed to the comprehension of the importance of this issue and awareness of further improvement of PE teaching and students' and teachers' roles in teaching-learning practices accomplished by the use of technologies and digital education. The theoretical section of this paper analyses various theoretical, pedagogical, cognitive and methodological aspects of digitalisation and digital education in $\mathrm{PE}$ teaching by means of the method of theoretical analysis. The method used in the empirical section of the paper was the descriptive method. PE teachers' attitudes towards digital education in PE teaching were received by means of a survey and scaling techniques and the use of the questionnaire and the Likert-type assessment scale, named Digital education in physical education (DOUF/DEIP). The questionnaire comprised four close-ended questions, and the Likert scale contained 40 items, equally distributed in four subscales in accordance with the aforementioned research tasks. The examination of the metric characteristics of the instrument by means of Cronbach's Alpha coefficient (Cronbach's Alpha $=0.961$ ) proved that the constructed instrument was reliable, i.e., that the elements were consistent and valid for the subject matter of the research.

The research was conducted in central and southern Serbia in May and June 2020. The respondents were granted confidentiality regarding their responses in the questionnaire. Due to the current COVID-19 epidemiological situation, the research was conducted in two ways: by using the application Google questionnaire online and in the field, respecting all the measures prescribed for the prevention of the spread of the coronavirus disease. The research sample was not based on the probability sampling technique, i.e. it was not selected using a random selection. The selection of the respondents was governed by the teachers' decision and desire to participate in the research. The sample comprised $126 \mathrm{PE}$ teachers. As regards the gender, there were 64 male teachers $(50.8 \%)$ and 62 female teachers $(49.2 \%)$, which proved an almost even number of teachers of both genders teaching this school subject. Regarding teaching experience, there were 46 teachers with 0 to 10 years' teaching experience $(36.5 \%), 53$ teachers who had been teaching for 11 to 20 years $(42.1 \%)$ and 27 teachers with the teaching experience longer than 20 years $(21.4 \%)$. Concerning the type of school, there were $73(57.9 \%)$ primary school PE teachers and 53 (42.1\%) secondary school PE teachers. 
The obtained results were calculated by the SPSS software version 24 , used for the statistical data processing. The following statistical parameters for displaying results were used: frequency (f), percentage $(\%)$, arithmetic mean (M), standard deviation (SD), Pearson's chi-squared test $(\chi 2)$, the t-test and ANOVA F-test.

\section{RESULTS}

The first part of the instrument was a questionnaire containing four close-ended questions. The questionnaire examined the first research task related to digital competences and digital education in PE teaching. Possible statistically significant differences in the frequencies of the respondents' replies to the posed questions were examined by Pearson's chi-squared test. It should be emphasised that the cross reference of the independent variable gender with the dependent variables of the first research task did not show statistically significant differences in the frequencies of the responses. The conclusion is that PE teachers of both genders provided homogenous responses to the question presented in Table 1. This segment of statistical data processing was not shown in the table due to the lack of statistically significant difference in the frequencies of the respondents' responses.

Table 1 Differences in the obtained responses about digital competences regarding teaching experience

\begin{tabular}{|c|c|c|c|c|c|c|}
\hline & & & \multicolumn{3}{|c|}{ Teaching experience (years) } & \multirow[t]{2}{*}{ Total: } \\
\hline & & & $0-10$ & $11-20$ & Over 20 & \\
\hline \multirow{6}{*}{$\begin{array}{l}\text { Digital } \\
\text { competences } \\
\text { involve: }\end{array}$} & \multirow{2}{*}{ Browsing the Internet } & $\mathrm{f}$ & 12 & 4 & 11 & 27 \\
\hline & & $\%$ & 9.5 & 3.2 & 8.7 & 21.4 \\
\hline & \multirow{2}{*}{$\begin{array}{l}\text { Use of information and } \\
\text { communication technologies }\end{array}$} & $\mathrm{f}$ & 34 & 48 & 15 & 97 \\
\hline & & $\%$ & 27 & 38.1 & 11.9 & 77.0 \\
\hline & \multirow{2}{*}{ Use of social media } & $\mathrm{f}$ & 0 & 1 & 1 & 2 \\
\hline & & $\%$ & 0 & 0.8 & 0.8 & 1.6 \\
\hline \multirow[t]{2}{*}{ Total: } & & $\mathrm{f}$ & 46 & 53 & 27 & 126 \\
\hline & & $\%$ & 36.5 & 42.1 & 21.4 & 100 \\
\hline
\end{tabular}

$\chi^{2}=14.39 ; \mathrm{df}=4 ; \mathrm{p}=0.01 ; \mathrm{C}=0.24$

Table 1 displays a statistically significant difference in the respondents' replies to the question about digital competences regarding their teaching experience. The statistically significant difference was $\mathrm{p}<0.05(\mathrm{p}=0.01)$. The majority of the respondents $(77.0 \%)$ thought that digital competences involved the use of information and communication technologies, whereas a smaller number of them $(21.4 \%)$ indicated that digital competences involved browsing the Internet. A negligible number of the respondents (1.6\%) emphasised the use of social media as a digital competence. The conclusion is that the majority of teachers understood the fundamental concept of digital competences, which considerably contributes to a positive attitude towards digitalisation of PE teaching.

The distribution of the responses to the second question from the questionnaire, Can you assess the level of your digital competence? was the following: more than half of the respondents $(76.2 \%)$ said that they had enough skills, knowledge and experience for using technologies, while a small number of them (23.8\%) gave contrary answers. Table 2 shows a statistically significant difference in the respondents' replies regarding their teaching experience. This statistically significant difference was estimated as $\mathrm{p}<0.05$ 
$(p=0.00)$. The obtained results prove that more than half of the respondents believed they possessed a sufficient number of competences, crucial for the introduction and implementation of the idea of digital education into PE teaching. This further proves that $\mathrm{PE}$ teachers are qualified for the application of technologies with the purpose of accomplishing better teaching outcomes.

Table 2 Differences in the obtained responses about digital competence self-assessment regarding teaching experience

\begin{tabular}{|c|c|c|c|c|c|c|}
\hline & & & \multicolumn{3}{|c|}{ Teaching experience (years) } & \multirow[t]{2}{*}{ Total: } \\
\hline & & & $0-10$ & $11-20$ & Over 20 & \\
\hline \multirow{4}{*}{$\begin{array}{l}\text { Can you } \\
\text { assess the } \\
\text { level of your } \\
\text { digital } \\
\text { competence? }\end{array}$} & I think that I have enough & $\mathrm{f}$ & 46 & 37 & 13 & 96 \\
\hline & $\begin{array}{l}\text { knowledge, skills and experience } \\
\text { for using technologies }\end{array}$ & $\%$ & 36.5 & 29.4 & 10.3 & 76.2 \\
\hline & I do not think that I have enough & $f$ & 0 & 16 & 14 & 30 \\
\hline & $\begin{array}{l}\text { knowledge, skills and experience } \\
\text { for using technologies }\end{array}$ & $\%$ & 0.0 & 12.7 & 11.1 & 23.8 \\
\hline Total: & & $\begin{array}{c}\mathrm{f} \\
\% \\
\end{array}$ & $\begin{array}{c}46 \\
36.5 \\
\end{array}$ & $\begin{array}{c}53 \\
42.1 \\
\end{array}$ & $\begin{array}{c}27 \\
21.4 \\
\end{array}$ & $\begin{array}{l}126 \\
100 \\
\end{array}$ \\
\hline
\end{tabular}

$$
\chi^{2}=27.27 ; \mathrm{df}=2 ; \mathrm{p}=0.00 ; \mathrm{C}=0.47
$$

Besides the aforementioned statistical significance, a statistically significant difference was evident in the frequency of the responses to the posed question regarding the school in which the respondents were employed as PE teachers $\left(\chi^{2}=3.83 ; \mathrm{df}=1 ; p=0.05(\mathrm{p} \leq 0.05)\right.$; $\mathrm{C}=0.17$ ), more precisely whether they taught PE in primary or in secondary school. Therefore, the conclusion is that differences were detected in the respondents' replies to the question about digital competence self-assessment in relation to their teaching experience and the school in which they taught.

What follows are the responses to the question about the concept of digital education:

Table 3 Differences in the obtained responses about the concept of digital education regarding the school facilities

\begin{tabular}{|c|c|c|c|c|c|}
\hline & & & \multicolumn{2}{|c|}{ School } & \multirow[b]{2}{*}{ Total: } \\
\hline & & & $\begin{array}{c}\text { Primary } \\
\text { school }\end{array}$ & $\begin{array}{c}\text { Secondary } \\
\text { school }\end{array}$ & \\
\hline \multirow{6}{*}{$\begin{array}{l}\text { The concept } \\
\text { of digital } \\
\text { education is: }\end{array}$} & Computer- and & $\mathrm{f}$ & 33 & 6 & 39 \\
\hline & Internet-assisted learning & $\%$ & 26.2 & 4.8 & 31.0 \\
\hline & Technical equipment & $\mathrm{f}$ & 2 & 0 & 2 \\
\hline & and devices in schools & $\%$ & 1.6 & 0.0 & 1.6 \\
\hline & Academic achievements & $\mathrm{f}$ & 38 & 47 & 85 \\
\hline & accomplished by applying technology & $\%$ & 30.2 & 37.3 & 67.5 \\
\hline \multirow{2}{*}{ Total: } & & $\mathrm{f}$ & 73 & 53 & 126 \\
\hline & & $\%$ & 57.9 & 42.1 & 100 \\
\hline
\end{tabular}

$\chi^{2}=18.95 ; \mathrm{df}=2 ; \mathrm{p}=0.00 ; \mathrm{C}=0.39$

A statistically significant difference was determined in the responses about the concept of digital education regarding the school in which the respondents were employed as teachers. The difference was estimated as $\mathrm{p}<0.05(\mathrm{p}=0.00)$. Namely, Table 3 
shows that more than half of the respondents (67.5\%) acknowledged that digital education meant the accomplishment of academic achievements by the application of technology. A smaller number of the respondents $(31.0 \%)$ stated that computer- and Internet-assisted learning represented the concept of digital education, while the smallest number of the respondents $(1.6 \%)$ equated the concept of digital education with technical equipment and devices in schools. It can be concluded that the majority of the PE teachers who participated in this research understood the concept of digital education correctly, which is a significant contribution to the further improvement of PE teaching. No differences were detected in the responses regarding the variable teaching experience, which implied that these responses could be considered homogenous concerning this independent variable.

The last question in the questionnaire was Why do you think it is necessary to introduce technology into physical education classes?. The responses are presented in the table.

Table 4 Differences in the obtained responses about the necessity of introducing technology into physical education regarding the school facilities

\begin{tabular}{|c|c|c|c|c|c|}
\hline & & & \multicolumn{2}{|c|}{ School } & \multirow[t]{2}{*}{ Total: } \\
\hline & & & $\begin{array}{l}\text { Primary } \\
\text { school }\end{array}$ & $\begin{array}{c}\text { Secondary } \\
\text { school }\end{array}$ & \\
\hline \multirow{6}{*}{$\begin{array}{l}\text { Why do you } \\
\text { think it is } \\
\text { necessary to } \\
\text { introduce } \\
\text { technology } \\
\text { into physical } \\
\text { education } \\
\text { classes? }\end{array}$} & \multirow{2}{*}{$\begin{array}{l}\text { Students use technology in everyday life, } \\
\text { so it should be used in physical education } \\
\text { classes as well. }\end{array}$} & $\mathrm{f}$ & 4 & 1 & 5 \\
\hline & & $\%$ & 3.2 & 0.8 & 4.0 \\
\hline & \multirow{2}{*}{$\begin{array}{l}\text { Technology is used in all school subjects, } \\
\text { so physical education } \\
\text { should not differ. }\end{array}$} & $\mathrm{f}$ & 48 & 14 & 62 \\
\hline & & $\%$ & 38.1 & 11.1 & 49.2 \\
\hline & \multirow{2}{*}{$\begin{array}{l}\text { Physical education curricula allow teachers } \\
\text { to be creative, which can be accomplished } \\
\text { by the application of technology. }\end{array}$} & $\mathrm{f}$ & 21 & 38 & 59 \\
\hline & & $\%$ & 16.7 & 30.2 & 46.8 \\
\hline \multirow{2}{*}{\multicolumn{2}{|c|}{ Total: }} & $\mathrm{f}$ & 73 & 53 & 126 \\
\hline & & $\%$ & 57.9 & 42.1 & 100 \\
\hline
\end{tabular}

A statistically significant difference in the responses about the necessity of introducing technology into PE classes was determined regarding the school in which the respondents were employed as teachers. The difference was estimated as $\mathrm{p}<0.05$ $(\mathrm{p}=0.00)$. Table 4 displays that almost half of the respondents $(49.2 \%)$ stated that the reason for introducing technology into PE classes was conditioned by the fact that technology was applied in all school subjects and that PE should not be treated differently. Less than half of the respondents (46.8\%) replied that PE curricula allowed teachers to be creative, which could most easily be accomplished by the application of technology, whereas the smallest number of respondents $(4.0 \%)$ thought that technology should be introduced into physical education classes because of students' everyday use and knowledge of modern technologies.

A statistically significant difference was detected in the frequency of the obtained responses to the posed question regarding the independent variable teaching experience $\left(\chi^{2}=11.15 ; \mathrm{df}=4 ; p=0.03(\mathrm{p}<0.05) ; \mathrm{C}=0.21\right)$. Therefore, the obtained results prove that the 
respondents' replies to the question about the reasons for introducing technology into PE classes differed regarding the dependent research variables.

Table 5 Differences in the obtained responses about digitalisation of physical education teaching regarding gender

\begin{tabular}{lccccccc}
\hline & Gender & $\mathrm{N}$ & $\mathrm{M}$ & $\mathrm{SD}$ & $\mathrm{t}$ & $\mathrm{df}$ & $\mathrm{p}$ \\
\hline Technologies used in physical education & Male & 64 & 32.78 & 5.99 & \multirow{2}{*}{-3.86} & \multirow{2}{*}{121} & \multirow{2}{*}{0.00} \\
& Female & 62 & 36.55 & 4.94 & & & \\
teaching & Male & 64 & 41.03 & 5.00 & \multirow{2}{*}{-7.25} & \multirow{2}{*}{122} & \multirow{2}{*}{0.00} \\
\hline Connection between digital education and & Female & 62 & 46.98 & 4.20 & & & \\
quality of physical education teaching & Male & 64 & 36.03 & 6.33 & \multirow{2}{*}{-5.54} & \multirow{2}{*}{124} & \multirow{2}{*}{0.00} \\
\hline Connection between digital education and & Female & 62 & 42.90 & 7.56 & & & \\
students' achievements in physical education & Male & 64 & 36.58 & 6.74 & \multirow{2}{*}{-5.98} & \multirow{2}{*}{124} & \multirow{2}{*}{0.00} \\
\hline $\begin{array}{l}\text { Connection between digital education and the } \\
\text { teacher's role in physical education }\end{array}$ & Female & 62 & 43.81 & 6.82 & & & \\
\hline
\end{tabular}

Table 5 displays the results obtained from the responses to the research questions regarding the independent variable of gender. The data were statistically processed and a statistically significant difference in the responses was determined by means of the t-test. Regarding the first research task related to the respondents' attitudes towards the technology used in PE teaching, the female respondents $(M=36.55)$ expressed greater preference than the male teachers $(M=32.78)$. Namely, the female PE teachers used video cameras, LCD projectors, MP3 players, mobile phones, computers, the Internet and other technological devices and media during PE classes more frequently than their male counterparts. Based on the value of the statistical significance $(\mathrm{p}=0.00)$ and in accordance with $\mathrm{p}<0.05$, a statistically significant difference was determined in the obtained responses regarding gender. Statistically significant values of $p=0.00(p<0.05)$ were evident for the responses to the items in the remaining three research questions regarding the respondents' gender. As regards the connection between digital education and the quality of PE teaching, the female respondents $(M=46.98)$ expressed more positive attitudes and valued the connection between digital education and the quality of teaching more than the male respondents. Also, the female PE teachers $(M=42.90)$ had more positive attitudes towards the connection between digital education and students' achievements than their male counterparts $(\mathrm{M}=36.03)$. A statistically significant difference was detected in the responses about the connection between digital education and the teacher's role. The female respondents $(M=43.81)$ assessed this connection more positively than the male PE teachers. It is concluded that there were statistically significant differences in the obtained responses to the four research tasks regarding the respondents' gender and that female respondents expressed more positive attitudes than their male counterparts. 
Table 6 Differences in the obtained responses about digitalisation of physical education teaching regarding the school facilities

\begin{tabular}{|c|c|c|c|c|c|c|c|}
\hline & School & $\mathrm{N}$ & $\mathrm{M}$ & SD & $\mathrm{t}$ & $\mathrm{df}$ & $\mathrm{p}$ \\
\hline \multirow{2}{*}{$\begin{array}{l}\text { Technologies used in physical } \\
\text { education teaching }\end{array}$} & $\begin{array}{l}\text { Primary } \\
\text { school }\end{array}$ & 73 & 34.80 & 6.26 & \multirow{2}{*}{-0.56} & \multirow{2}{*}{122} & \multirow{2}{*}{0.58} \\
\hline & $\begin{array}{l}\text { Secondary } \\
\text { school }\end{array}$ & 53 & 34.96 & 5.13 & & & \\
\hline \multirow{2}{*}{$\begin{array}{l}\text { Connection between digital } \\
\text { education and quality of physical } \\
\text { education teaching }\end{array}$} & $\begin{array}{l}\text { Primary } \\
\text { school }\end{array}$ & 73 & 42.80 & 6.03 & \multirow{2}{*}{-3.01} & \multirow{2}{*}{124} & \multirow{2}{*}{0.00} \\
\hline & $\begin{array}{l}\text { Secondary } \\
\text { school }\end{array}$ & 53 & 45.55 & 4.19 & & & \\
\hline \multirow{2}{*}{$\begin{array}{l}\text { Connection between digital } \\
\text { education and students' } \\
\text { achievements in physical education }\end{array}$} & $\begin{array}{l}\text { Primary } \\
\text { school }\end{array}$ & 73 & 38.33 & 8.86 & \multirow{2}{*}{-2.00} & \multirow{2}{*}{122} & \multirow{2}{*}{0.05} \\
\hline & $\begin{array}{l}\text { Secondary } \\
\text { school }\end{array}$ & 53 & 40.91 & 5.62 & & & \\
\hline \multirow{2}{*}{$\begin{array}{l}\text { Connection between digital } \\
\text { education and the teacher's role in } \\
\text { physical education }\end{array}$} & $\begin{array}{l}\text { Primary } \\
\text { school }\end{array}$ & 73 & 39.27 & 7.96 & \multirow{2}{*}{-1.49} & \multirow{2}{*}{124} & \multirow{2}{*}{0.13} \\
\hline & $\begin{array}{l}\text { Secondary } \\
\text { school }\end{array}$ & 53 & 41.32 & 7.15 & & & \\
\hline
\end{tabular}

One of the independent research variables was the school in which the respondents were employed as PE teachers. Using the statistical parameter t-test, a statistically significant difference was determined in the responses regarding this independent variable. Table 6 shows that the responses about the technologies used in PE teaching did not differ significantly regarding the school in which the teachers were employed, i.e. the responses provided by primary and secondary school teachers were homogenous. Both primary and secondary school PE teachers responded in the same manner concerning the technological devices that could be used in PE teaching ( $p>0.05 ; \mathrm{p}=0.58$ ). The responses obtained from secondary school teachers $(\mathrm{M}=45.55)$ differed from those provided by primary school $\mathrm{PE}$ teachers $(\mathrm{M}=42.80)$ regarding the second question related to the connection between digital education and the quality of PE teaching. The difference was estimated as statistically significant $\mathrm{p}<0.05 \quad(\mathrm{p}=0.00)$. Secondary school teachers expressed more positive attitudes towards the connection between digital education and the quality of PE teaching than primary school teachers. These attitudes reflected the idea that digital education could enrich, modernise and improve this school subject and that it could be applied in planning, realising and evaluating PE teaching with the purpose of accomplishing all educational and teaching goals established by school curricula. Also, there was a statistically significant difference in the respondents' attitudes towards the connection between digital education and students' achievements in PE. Namely, secondary school teachers $(\mathrm{M}=40.91)$ expressed more positive attitudes than primary school PE teachers $(M=38.33)$, which means that secondary school teachers could better perceive and understand the concept of digital education as crucial in improving students' achievements, motivation and interests in PE. The difference was determined as statistically significant $\mathrm{p} \leq 0.05(\mathrm{p}=0.05)$. Finally, the responses of both secondary and primary school teachers were homogenous regarding the connection between digital education and the teacher's role in PE teaching. The obtained responses did not differ 
significantly $(p>0.05 ; p=0.13)$ regardless of the school in which the respondents were employed as PE teachers.

The Anova F test was used to determine statistically significant differences in the responses regarding teaching experience.

Table 7 Differences in the obtained responses about digitalisation of physical education teaching regarding teaching experience

\begin{tabular}{|c|c|c|c|c|c|c|c|}
\hline & $\begin{array}{l}\text { Teaching } \\
\text { experience }\end{array}$ & $\mathrm{N}$ & M & $\mathrm{SD}$ & $\mathrm{F}$ & $\mathrm{df}$ & $\mathrm{p}$ \\
\hline \multirow{3}{*}{$\begin{array}{l}\text { Technologies used in physical } \\
\text { education teaching }\end{array}$} & $0-10$ & 46 & 36.41 & 5.67 & \multirow{3}{*}{11.03} & \multirow{3}{*}{2} & \multirow{3}{*}{0.00} \\
\hline & $11-20$ & 53 & 35.22 & 5.04 & & & \\
\hline & Over 20 & 27 & 30.44 & 5.50 & & & \\
\hline \multirow{3}{*}{$\begin{array}{l}\text { Connection between digital } \\
\text { education and quality of physical } \\
\text { education teaching }\end{array}$} & $0-10$ & 46 & 44.61 & 3.26 & \multirow{3}{*}{0.95} & \multirow{3}{*}{2} & \multirow{3}{*}{0.39} \\
\hline & $11-20$ & 53 & 44.00 & 7.05 & & & \\
\hline & Over 20 & 27 & 42.78 & 4.98 & & & \\
\hline \multirow{3}{*}{$\begin{array}{l}\text { Connection between digital } \\
\text { education and students' } \\
\text { achievements in physical education }\end{array}$} & $0-10$ & 46 & 41.00 & 4.83 & \multirow{3}{*}{10.80} & \multirow{3}{*}{2} & \multirow{3}{*}{0.00} \\
\hline & $11-20$ & 53 & 40.93 & 8.07 & & & \\
\hline & Over 20 & 27 & 33.70 & 8.65 & & & \\
\hline \multirow{3}{*}{$\begin{array}{l}\text { Connection between digital } \\
\text { education and the teacher's role in } \\
\text { physical education }\end{array}$} & $0-10$ & 46 & 41.39 & 6.08 & \multirow{3}{*}{6.81} & \multirow{3}{*}{2} & \multirow{3}{*}{0.00} \\
\hline & $11-20$ & 53 & 41.40 & 8.26 & & & \\
\hline & Over 20 & 27 & 35.52 & 7.36 & & & \\
\hline
\end{tabular}

The responses obtained from the teachers with 0 to 10 years of teaching experience $(M=36.41)$ showed that they favoured the use of technologies in PE classes in comparison to their more experienced colleagues. The difference in the responses was statistically significant $p<0.05(p=0.00)$. This result was expected owing to the fact that younger PE teachers were more qualified for the application of technologies in teaching because of their digital competences and everyday use of technology. The respondents' attitudes towards the connection between digital education and the quality of PE teaching did not differ significantly $(p>0.05 ; p=0.39)$ regarding their teaching experience. From the point of view of statistics, the responses were analogous and equivalent. On the other hand, the data presented in Table 7 show that there was a statistically significant difference in the respondents' attitudes towards the connection between digital education and students' achievements in PE regarding the independent variable of teaching experience. This statistically significant difference was evaluated as $p<0.05(p=0.00)$. Namely, the PE teachers with 0 to 10 years of teaching experience $(M=41.00)$ expressed more positive attitudes than their more experienced colleagues, and they thought that the use of digital education and technologies could significantly contribute to students' academic achievements in PE. Since this group of teachers used technology in their classes more than their more experienced colleagues, it is logical that they ascribed their students' academic achievements to the application of technology in teaching. The displayed results also show that statistically significant differences were detected in the responses related to the last research task - the connection between digital education and the teacher's role in PE teaching. It is interesting that the PE teachers with 11 to 20 years of teaching experience $(M=41.40)$ indicated that the use of technology in PE teaching had a positive impact on their self-confidence, motivation, reputation, cooperation with colleagues and consequently on their role in PE teaching. It is assumed that teachers with 11 to 20 years of teaching 
experience displayed considerable understanding of the importance of technology and its use in teaching aimed at their own personal advancement and improvement as teachers, which is the reason why they provided the most positive responses compared to the responses of their less experienced and more experienced colleagues.

\section{DISCUSSION}

Digital education in PE presupposes the introduction of technologies into PE classes with the purpose of accomplishing the goals established by school curricula. The relevant sources state various factors that support digitalisation of PE teaching. Namely, Robinson (2011) emphasises that the omnipresent technology pervades every aspect of PE as a school subject. Consequently, it can easily be included into the framework of education. The introduction of technologies into PE classes does not reduce schoolchildren's physical activity but reveals new ways in which to become more active and raises their awareness about the importance of PE and general health. Moreover, information and communication technologies have already become an integral part of numerous school subject programmes. Digital technologies facilitate planning, programming, realisation and evaluation of teaching and are extremely beneficial for teachers (Ristić, 2018a). PE is a school subject that allows for the teacher's creativity in devising their classes to suit their students' needs (Višnjić \& Marković, 2018). Therefore, PE represents a fruitful ground for the use and further development of technologies and digital education.

There is a number of various technologies, media and multimedia that can be used with great success in PE classes. Besides the radio, the oldest and the most widely spread technical device is certainly the television. Although it belongs to the group of obsolete technologies, the television is used in schools in order to show certain educational programmes. Then, there are the video recorder and video cameras that record schoolchildren's moves, facilitate the study of certain sports techniques and have a very positive effect on young people's self-reflection and self-introspection (Calandra, Gurvitch, \& Lund, 2008; Baert, 2011; Casey \& Jones, 2011; Semiz \& Levent Ince, 2012; Bodsworth \& Goodyear, 2017). The LCD projector displays recorded materials by connecting the projector to the television set, video camera or video recorder (Kretschmann, 2010). The use of video cameras and video recorders provides feedback that mostly influences the acquisition of motor skills, which is the fundamental task of PE (Banville \& Polifko, 2009). Besides the aforementioned technologies, pedometers and heart rate monitors are unavoidable (Baert, 2011; Robinson, 2011; Semiz \& Levent Ince, 2012; Bodsworth \& Goodyear, 2017; Casey, Goodyear, \& Armour, 2017; Ristić, 2018a; Pang, Varea, Cavallin, \& Cupac, 2019). The pedometer is an instrument that measures the number of one's steps during a period of time, which is one of the indicators of the level of students' physical activity. On the other hand, heart rate monitors measure and display one's heart rate in real time and during physical exercise, which indicates one's physical fitness (Kretschmann, 2010; Baert, 2011).

Audio devices prove to be very useful in PE classes, particularly the MP3 player (Semiz \& Levent Ince, 2012). Certain dances and dance moves accompanied by recognisable music are also studied in PE. MP3 players play the required songs and music, which enables learning of necessary dance moves in the most natural way (Kretschmann, 2010). 
The greatest of all technological achievements of human intellect, the computer, is most widely used in teaching almost all of school subjects. This is further proved by the fact that only few classrooms are not equipped with computers. A further technological advancement has generated the laptop, a small, portable personal computer that can be also put to educational use. Personal computers can be used in various ways in PE classes. The computer can serve as the digital audio and video recorder that shows the materials recorded on compact disks (Casey \& Jones, 2011) or USB flash drives. The Internet has transformed the personal computer into a technology of limitless possibilities. It allows access to certain sites, web platforms and educational software related to PE. Additionally, teachers and students browse websites in search of data and information regarding the importance of physical activity, fitness programmes, sports, diets and promotion of healthy lifestyles. They share advice by email and are thus constantly connected and active outside school gyms (Gibbone, Rukavina, \& Silverman, 2010; Goran \& Reynolds, 2005). Kretschmann (2010) deliberates that educational software contains videos that display specific sports techniques, tactics and even the games played by professional athletes, which can all enhance PE teaching. The power of social media is not to be overlooked (Pang et al., 2019) since they are used to distribute PE teaching materials , maintain communication, and monitor students' and teachers' achievements in physical activities.

As it has already been mentioned, the children of today are digital natives. This is illustrated by the fact that life is unimaginable without mobile phones and technologies. Every segment of contemporary life is imbued with mobile technology, which justifies its application in PE. Numerous authors have indicated that the mobile phone represents yet another technological device beneficial for PE teaching (Kretschmann, 2010; Robinson, 2011; Semiz \& Levent Ince, 2012; Bodsworth \& Goodyear, 2017; Ristić, 2018a; Pang et al., 2019). Mobile phones, either with the android or iOS operative system (iPhone), allow downloading of mobile applications that are used for the visual presentations of certain sports games, appropriate training, step measuring, health promotion, healthy dietary habits and physical fitness. The following are some of the most popular free apps: Nike Training Club, Samsung Health, Fitonomy, Adidas Training by Runtastic, RunKeeper, Workout Trainer, Beep Test, Google Fitness, Home Workout Without Equipment, Physical Education, Pedometer, Heart Rate Plus, Step Counter, 30-Day Fitness Challenge, Arm Workout, Body Editor, Infinity Fit, Water Reminder and others. Although these apps are not directly related to teaching materials, they make PE classes more modern, flexible and dynamic. Similar to personal computers, mobile phones allow access to YouTube, which is teeming with educational videos that assist PE teachers in designing creative teaching materials to be taught in school gyms, sports fields or schoolyards. PE teachers use other sites as well, such as the TubeChop (selecting particular parts of video clips that are useful for classes of PE) and the Posterous (posting personal video clips in order to enhance the quality of PE teaching). Robinson (2011) states that mobile phones can assist in digitalisation of PE in a number of ways. Calendars and clocks are accessed by mobile phones, which facilitates the arrangement of training sessions during classes. They are equipped with a practical video camera used for recording various materials that are beneficial for students and their motivation for physical activity. Mobile phones download and reproduce audio materials to accompany physical exercise related to games, dancing practice, training or working-out. Particularly 
interesting are the GPS and QR codes, which stimulate students to compete in the number of completed tasks, exploration of nature and simultaneous physical exercise.

Tablets and iPad devices have proven very useful in PE classes. They are mainly used for playing video games, which dominate children's and adolescents' free time. However, video games can be appropriated for PE classes just like other technological innovations (Lin et al., 2006; Papastergiou, 2009; Gibbone et al., 2010; Mangen, 2010; Staiano \& Calvert, 2011; Semiz \& Levent Ince, 2012; Bodsworth \& Goodyear, 2017; Rajić \& Tasevska, 2019). They require a constant sensorimotor activity on the part of schoolchildren and thus have an effect on their behaviour (Chumbley \& Griffiths, 2006). They have to be used in PE classes cleverly. One of the versions of video games are sports games that simulate particular sports and allow students to participate in athletic exercise and activities (Baert, 2011). Therefore, they can be used as a means of instruction aimed at students' better understanding and learning the rules of the games presented. Also, electronic games create a desire among students to accomplish a goal (Papastergiou, 2009). On the other hand, more frequent are the games known as exergames, which are actually a combination of a game and physical exercise and consequently beneficial for students' health, coordination, cognition, feedback, concentration, motivation and academic achievement (Baert, 2011; Staiano \& Calvert, 2011; Maillot, Perrot, \& Hartley, 2012). The following are some of the popular games combined with physical exercise: Dance Dance Revolution, How Fit are Wii (Papastergiou, 2009; Robinson, 2011), Fish'n'Steps, Tagaboo (Lin et al., 2006), etc. The PE teacher should observe the importance of video games for their students and create teaching materials accordingly. This will result in schoolchildrens' better academic achievement and comprehension of the importance of PE.

The introduction of digitalisation into PE depends on the teacher's digital and information competences. Digital competences are defined as one's competences to use information and communication technologies at work, in personal and social life and everyday communication in a secure and critical manner (Ristić \& Blagdanić, 2017: 3). All teaching activities that are supported by information technologies demand that teachers be digitally qualified and possess the knowledge and skills acquired by education and professional training. According to Ristic (2018a: 49; 2018b) the teachers' education and training for the application of information and communication technologies in teaching comprises four phases: 1. Detection of the digital technologies' potential in teaching; 2. Learning how to use digital technologies; 3 . Understanding where and when to use digital technologies; 4. Specialising in the use of digital technologies depending on the school subject taught. Regarding physical education, the teachers' and students' digital technologies are an integral part of contemporary teaching and should be promoted in PE (Vogt, Rehlinghaus, \& Klein, 2019).

Research in the field has shown that the use of technologies in Serbian schools does not only depend on technical conditions and teachers' competences, but also on their enthusiasm and motivation to teach (Ristić, 2018b), as well as their self-confidence (Semiz \& Levent Ince, 2012). The most important task of PE is to prepare schoolchildren for a continuous and lifelong physical activity. Having the greatest influence on students (Casey et al., 2017), the PE teacher is expected to provide a teaching environment suited to their students' internal motivation (Koka \& Hein, 2003; Hans \& Crasta, 2019) and cooperation that will breed success and overcome obstacles. Numerous authors (Ntoumanis, 2001; Standage, Duda, \& Ntoumanis, 2003; Ntoumanis \& Standage, 2009) believe that students' motivation for PE represents a particular issue related to the contemporary trend 
of hedonistic and sedentary lifestyles. This issue may be resolved by the introduction of technologies into PE, which provide the feedback that stimulates students' physical efforts, desire and endeavours. This further proves that digital education in PE is indispensable in contemporary teaching. PE curricula are enriched by coordinating the already established academic achievements with the level of attained digital competences (Kretschmann, 2010). Digitalisation may be implemented into planning, programming, realisation and evaluation of $\mathrm{PE}$ teaching. The value of the applied technology is determined by its benefits for curricular and the majority of extracurricular activities (Ristić \& Blagdanić, 2017), which are more flexible and more suited to students' interests and which make this school subject specific. Understood as the means of further promotion of health, physical exercise and training, technology cannot have any negative effects on schoolchildren's and adolescents' present physical fitness and activity. Educational data can be accessed at any place and at any time via mobile phones, applications and educational software (Lin et al., 2006). Moreover, motivational video materials and the use of video cameras, personal computers or tablets can significantly improve students' health and raise their awareness of their personal growth, the importance of healthy lifestyles and continuous physical activity. Numerous sports video games positively influence students' attitudes towards a particular sports game or a professional athlete, which further motivates them to play sports, to do athletics or gymnastics. PE classes taught in school gyms become more innovative and interesting, stimulating students' inner and outer motives for a better performance. Therefore, the quality of PE teaching is higher and accorded with contemporary trends in education.

Contemporary education is characterised by the use of modern technologies and implementation of digital education. Also, an important task is to determine whether PE teaching is undergoing digitalisation and how this aspect is connected to the fundamental elements of teaching. It is very important to examine PE teachers' attitudes towards this educational phenomenon. The methodology used in this research is based on these theoretical postulates and applied in the empirical study of the technologisation of teaching-learning practices.

$\mathrm{PE}$ is a mandatory school subject whose particularities differentiate it from other school subjects. The goal of PE as a school subject is to stimulate schoolchildren's growth and development, adequate posture, motor abilities and skills, as well as to encourage their positive attitudes towards PE, physical exercise, sports and healthy lifestyle (Kretschmann, 2010; Džinović \& Martinović, 2018). The introduction of digital education into PE teaching is crucial for the accomplishment of the primary goals of this school subject. The introduction of technologies and the concept of digital education into PE teaching contributes to the coordination between teaching and daily activities since technologies have become common in all spheres of life (Robinson, 2011). Digital and information and communication technologies facilitate planning, programming, realising and evaluating of teaching since teachers are offered creative solutions to be applied during physical education classes in school gyms (Ristić, 2018a; Višnjić \& Marković, 2018). This can be accomplished if PE teachers possess sufficient digital competences regarding the use of information and communication technologies, which have become essential in contemporary education (Vogt et al., 2019). Research in this field (Kretschmann, 2015) proves that the introduction of technologies into PE classes depends directly on the level of the teacher's digital and information literacy. Therefore, teachers' further 
professional training should be based on acquiring digital competences and learning how to appropriately use technology as a powerful teaching tool.

Regarding other aspects of the concept of digital education in PE, certain studies (Perrota, 2013) discuss that the use of technology in teaching is particularly beneficial for teachers since it influences their self-confidence and the desire to use technology more frequently (Semiz \& Levent Ince, 2012). The use of technology in all curricular and extracurricular activities confirms that contemporary education is appropriate and synchronised with current trends. Moreover, the introduction of technology into PE teaching contributes to students' greater academic achievements, their motivation and the improvement of the teaching-learning atmosphere (Casey \& Jones, 2011). Also, some research (Yaman, 2008) proves that female teachers as well as younger teachers use technology in PE teaching more frequently than male teachers and more experienced teachers, which correlates with the results obtained in the research presented in this paper.

The mentioned research states that the use of technology and digital education are closely related to the quality of teaching, students' academic achievements and the teacher's role in PE. This proves that the issue of digital education in PE teaching is a scientifically based phenomenon, which is compatible with the findings of the empirical research presented.

\section{CONCLUSION}

The advantages of digital education in PE are numerous. Technical devices have become an integral part of teaching, occupying a central position in PE. One of the advantages of the introduction of digital education into PE teaching is its positive effect on all participants in the teaching-learning practice and on the better quality of teaching. The introduction of technology contributes primarily to the improvement and modernisation of PE teaching. This refers to the technological equipment to be installed in school gyms.

The results of this research prove that teachers properly understand the terms digital competence and digital education, and that they comprehend the reasons for the introduction of technology into PE teaching. Namely, more than half of the respondents (76.2\%) stated that they possessed enough competences, knowledge and skills for the use of technologies and digital education in PE teaching, which is one of the most significant findings of this research. The obtained results illustrate that PE teachers are considerably qualified for the application of technological devices in teaching in order to complete the tasks prescribed by school curricula. The research also confirms statistically significant differences in the obtained responses regarding teaching experience and the school in which the respondents were employed as teachers $(\mathrm{p}<0.05)$, but not regarding the gender of the respondents. Therefore, the respondents expressed very positive attitudes towards digital competences and digital education.

The respondents also showed positive attitudes towards the use of various digital devices in physical education teaching and stated that they readily used them in their classes (video cameras, LCD projectors, MP3 players, computers, mobile phones, etc.). The findings prove that technology was more frequently used by female teachers, teachers with 0 to 10 years of teaching experience, and secondary school PE teachers. As regards the connection between digital education and the quality of PE teaching, students' achievements and the teacher's role, a statistically significant difference was 
evident in the obtained responses regarding all three independent variables (gender, teaching experience and the school in which the teachers were employed, $\mathrm{p}<0.05$ ). Namely, the effects of digitalisation on the quality of teaching, students' achievements and the teacher's role were more positively evaluated by female teachers, teachers with 0 to 10 years of teaching experience, and secondary school PE teachers. It is thus concluded that digital education exerts an enormous influence on the quality of teaching since its introduction enhances all aspects of teaching and contributes to the promotion of healthy lifestyles. Students become more motivated and active in class, they cooperate better with their peers and achieve better results in their personal growth and development. Reputation, self-confidence, personal integrity, cooperation with colleagues and sharing advice are only some of the elements that are influenced by the use of technology. This leads to the conclusion that digital education is closely related to the teacher's role in teaching.

The conducted research implies the importance of the study of this educational phenomenon and recommends its further promotion with the purpose of improving PE teaching as one of the most important school subjects.

\section{REFERENCES}

Baert, H. (2011). The integration of technology within physical education teacher education: Perceptions of the faculty. Doctoral Dissertation. Fayetteville: University of Arkansas.

Baltezarević, B., \& Baltezarević, V. (2019). eSports as a new playground. Facta Universitatis Series Physical Education and Sport, 17(1), 23-30.

Banville, D., \& Polifko, M. (2009). Using digital video recorders in physical education. Journal of Physical Education, Recreation and Dance, 80(1), 17-21.

Bodsworth, H., \& Goodyear, V. (2017). Barriers and facilitators to using digital technologies in the Cooperative Learning model in physical education. Physical Education and Sport Pedagogy, 22(6), 563-579.

Calandra, B., Gurvitch, R., \& Lund, J. (2008). An exploratory study of digital video editing as a tool for teacher preparation. Journal of Technology and Teacher Education, 16(2), 137-153.

Casey, A., \& Jones, B. (2011). Using digital technology to enhance student engagement in physical education. Asia-Pacific Journal of Health, Sport and Physical Education, 2(2), 51-65.

Casey, A., Goodyear, V.A., \& Armour, K.M. (2017). Rethinking the relationship between pedagogy, technology and learning in health and physical education. Sport, Education and Society, 22(2), 288-304.

Chumbley, J., \& Griffiths, M. (2006). Affect and the computer game player: the effect of gender, personality, and game reinforcement structure on affective responses to computer game-play. Cyber Psychology and Behavior, 9(3), 308-316.

Dobraš, R., Dragosavljević, P., Vučković, I., Gadžić, A., \& Lepir, D. (2013). The impact of the motivational intervention on students' motor abilities. Fizička kultura, 67(1), 24-32.

Džinović, D., \& Martinović, D. (2018). Savremene tehnologije u fizičkom vaspitanju kao faktor poboljšanja motoričkih sposobnosti dece. Inovacije $u$ nastavi (Modern technologies in physical education for improving the motor skills of children), Inovacije u nastavi, 31(3), 88-95. In Serbian

Gibbone, A., Rukavina, P., \& Silverman, S. (2010). Technology integration in secondary physical education: Teachers' attitudes and practice. Journal of Educational Technology Development and Exchange, 3(1), 27-42.

Goran, M., \& Reynolds, K. (2005). Interactive multimedia for promoting physical activity (IMPACT) in children. Obesity Research, 13(4), 762-771.

Gordon-Larsen, P., McMurray, R.G., \& Popkin, B.M. (2000). Determinants of adolescent physical activity and inactivity patterns. Pediatrics, 105(6), 1-8.

Hans, V.B., \& Crasta, S.J. (2019). Digitalization in the $21^{\text {st }}$ century-Impact on learning and doing. Journal of Global Economy, 15(1), 12-24.

Koka, A., \& Hein, V. (2003). Perceptions of teacher's feedback and learning environment as predictors of intrinsic motivation in physical education. Psychology of Sport and Exercise, 4(1), 333-346. 
Kretschmann, R. (2010). Physical education 2.0. In: M. Ebner \& M. Schiefner (Eds.), Looking toward the future of technology-enhanced education: Ubiquitous learning and the digital native, (pp. 432-454). Hershey, PA: IGI Publishing.

Kretschmann, R. (2015). Effect of physical education teachers' computer literacy on technology use in physical education. The Physical Educator, 72(5), 261-277.

Lin, J.J., Mamykina, L., Lindtner, S., Delajoux, G., \& Strub, H.B. (2006). Fish'n'Steps: Encouraging physical activity with an interactive computer game. In: P. Dourish, \& A. Friday (Eds.). International Conference on Ubiquitous Computing, (pp. 261-278). Springer-Verlag, Berlin, Heidelberg.

Maillot, P., Perrot, A., \& Hartley, A. (2012). Effects of interactive physical-activity video-game training on physical and cognitive function in older adults. Psychology and Aging, 27 (3), 589-600.

Mangen, A. (2010). Point and click: Theoretical and phenomenological reflections on the digitization of early childhood education. Contemporary Issues in Early Childhood, 11(4), 415-431.

Mihajlović, I., Smajić, M., \& Sente, J. (2010). Učestalost deformiteta stopala kod devojčica predškolskog uzrasta (Frequency of foot deformity in preschool girls). Vojnosanitetski pregled, 67(11), 928-932. In Serbian

Ntoumanis, N. (2001). A self-determination approach to the understanding of motivation in physical education. British Journal of Educational Psychology, 71(1), 225-242.

Ntoumanis, N., \& Standage, M. (2009). Motivation in physical education classes: a self-determination theory perspective. Theory and Research in Education, 7(2), 194-202.

Pang, B., Varea, V., Cavallin, S., \& Cupac, A. (2019). Experiencing risk, surveillance, and prosumption: Health and physical education students' perceptions of digitised health and physical activity data. Sport, Education and Society, 24(8), 801-813.

Papastergiou, M. (2009). Exploring the potential of computer and video games for health and physical education: a literature review. Computers and Education, 53(1), 603-622.

Perrotta, C. (2013). Do school-level factors influence the educational benefits of digital technology? A critical analysis of teachers' perceptions. British Journal of Educational Technology, 44(2), 314-327.

Rajić, S., \& Tasevska, A. (2019). The role of digital games in children's life. Inovacije u nastavi, 32(4), 97-108.

Ristić, M., \& Blagdanić, S. (2017). Nove perspektive u obrazovanju-vanučionička nastava u digitalnom okruženju (New perspectives in education: Extracurricular teaching in the digital environment). Inovacije $u$ nastavi, 30(2), 1-14. In Serbian

Ristić, M. (2018a). Integracija mobilnih tehnologija u nastavu fizičkog vaspitanja. Inovacije u nastavi, 31(2), 41-52.

Ristić, M. (2018b). Digitalne kompetencije nastavnika i saradnika (Digital competencies of teachers and associates). In: V. Katić (Ed.). 24. skup "Trendovi razvoja: digitalizacija visokog obrazovanja" (Conference "Development trends: Digitalization of higher education"), (pp. 123-126). Kopaonik: Faculty of Technical Sciences, University of Novi Sad. In Serbian

Robinson, J. (2011). 100 Ways to Use Technology in Physical Education. Retrieved March 15, 2020 from the: http://edt315.weebly.com/uploads/4/5/3/2/4532212/100_ways_to_use_technology_in_pe.pdf

Sandeep, S. (2011). Learning system for digitalization of an educational institution. United States Patent Application Publication, 1, 1-12.

Semiz, K., \& Levent Ince, M. (2012). Pre-service physical education teachers' technological pedagogical content knowledge, technology integration self-efficacy and instructional technology outcome expectations. Australasian Journal of Educational Technology, 28(7), 1248-1265.

Staiano, A., \& Calvert, S. (2011). Exergames for physical education courses: Physical, social, and cognitive benefits. Child Development Perspectives, 5(2), 93-98.

Standage, M., Duda, J.L., \& Ntoumanis, N. (2003). A model of contextual motivation in physical education: Using constructs from self-determination and achievement goal theories to predict physical activity intentions. Journal of Educational Psychology, 95(1), 97-110.

Višnjić, D., \& Marković, M. (2018). Mišljenja nastavnika o programima fizičkog vaspitanja u starijim razredima osnovne škole kao osnova za njihovo inoviranje (Opinions of teachers about the programmes of physical education in the higher grades of primary school as a basis for their innovation). Inovacije $u$ nastavi, 31(2), 94-100. In Serbian

Vogt, T., Rehlinghaus, K., \& Klein, D. (2019). School sport facing digitalisation: a brief conceptual review on a strategy to teach and promote media competence transferred to physical education. Journal of Physical Education and Sport, 19(4), 1424-1428.

Yaman, C. (2008). The abilities of physical education teachers in educational technologies and multimedia. Turkish Online Journal of Educational Technology, 7(2), 20-31. 


\section{PEDAGOŠKI, KOGNITIVNI I METODOLOŠKI ASPEKTI DIGITALIZACIJE U FIZIČKOM VASPITANJU}

Implementacija tehnologije digitalnog obrazovanja u školski predmet fizičkog vaspitanja (FV) predstavlja izazov savremenoj pedagogiji. Aktuelni rad naglašava značaj pedagoških, kognitivnih $i$ metodoloških aspekata digitalizacije u fizičkom vaspitanju. U okviru istraživanja su ispitivani stavovi nastavnika FV u osnovnim i srednjim školama prema digitalizaciji u FV. Istraživanje ima tri cilja: 1. teorijski - pregled svih međunarodnih $i$ nacionalnih izvora relevantnih za sagledavanje teorijskih aspekata uvođenja digitalizacije u nastavu $F V$; 2. kognitivni - proučavanje stavova nastavnika FV prema digitalizaciji u FV kao školskom predmetu; 3. primenljivost - doprinos podizanju svesti o značaju unapređenja FV. Metode koje su korišćene u empirijskom istraživanju bile su deskriptivna metoda, anketa i tehnika skaliranja sa upitnikom kao instrumentom i ocena Likertovog tipa (DOUF/DEIP). Upitnik se sastojao od četiri zatvorena pitanja i skale koja je sadržavala 40 itema. Uzorak je obuhvatio 126 nastavnika FV iz Srbije. Rezultati su dobijeni upotrebom softvera za statističku obradu podataka SPSS verzija 24. U prikazu rezultata korišćeni su sledeći statistički parametri: frekvencija $(f)$, procenat (\%), aritmetička sredina $(M)$, standardna devijacija (SD), Pearsonov hi-kvadrat test $\left(\mathrm{ch}^{2}\right)$, t-test i ANOVA F-test. Rezultati istraživanja pokazuju da se nastava FV podvrgava digitalizaciji i da nastavnici imaju pozitivan stav prema digitalnim kompetencijama, tehnologijama i prema vezi između digitalnog obrazovanja i kvaliteta nastave, akademskih dostignuća školaraca i uloge nastavnika.

Ključne reči: fizičko vaspitanje, digitalizacija, tehnologija, nastavnici u osnovnim i srednjim školama, empirijsko istraživanje 